\title{
KEBEBASAN HAK SOSIAL-POLITIK DAN PARTISIPASI WARGA NEGARA DALAM SISTEM DEMOKRASI DI INDONESIA
}

\author{
Muten Nuna \\ Fakultas Hukum, Universitas Gorontalo, \\ E-mail: mutensnuna@gmail.com \\ Roy Marthen Moonti \\ Fakultas Hukum, Universitas Gorontalo, \\ E-mail: roymoonti16@gmail.com
}

\begin{abstract}
Abstrak
Prinsip dari sebuah negara demokrasi adalah dengan menjunjung tinggi Konstitusi dan ideologi dalam sebuah negara. Kebebasan dalam hak sosial dan politik menjadi sebuah jaminan yang sangat diperlukan untuk dapat mencapai sebuah negara yang menjunjung tinggi demokrasi sehingga aspirasi yang ada dapat tersalurkan dengan baik. Permasalahan yang muncul yaitu Bagaimana Prinsip Dan Jaminan Hak Warga Negara Menurut UUD 1945 dan Bagaimana Dinamika Sosial Politik Dalam Sistem Demokrasi di Indonesia. Metode penelitian yang digunakan berupa penelitian hukum yuridis normatif yang merupakan penelitian kepustakaan, yaitu penelitian terhadap bahan hukum primer dan bahan hukum sekunder yang terdiri dari peraturan perundang-undangan dan literatur-literatur terkait untuk memecahkan persoalan hukum atau permasalahan yang akan dibahas. Kemerdekaan menyampaikan pendapat dimuka umum harus dilaksanakan dengan bertanggung jawab, sejalan dengan ketentuan peraturan perundang-undangan yang berlaku. Oleh karena itu negara wajib dapat mengelola dan mengendalikan dominasi iklim kapitalis agar tetap berjalan pada koridor yang tidak merugikan warga. Negara juga harus membuka dan memberdayakan ruang publik secara optimal sebagai instrumen warga dalam menyalurkan aspirasinya, serta menutup keran tumbuh suburnya praktek politik uang baik di kalangan elit politik maupun di kalangan masyarakat, karena dengan membiarkan politik uang berlangsung, maka tidak hanya berimpilkasi melahirkan politisi yang korup dan mengekang hati nurani masyarakat dalam memberikan partisipasi politiknya, namun juga berakibat tercederainya suatu pemilu yang demokratis.
\end{abstract}

Kata Kunci : Hak Sosial Politik; Partisipasi; Demokrasi. 


\title{
INDEPENDENCY OF SOCIAL-POLITICAL RIGHTS AND PARTICIPATION OF CITIZEN IN DEMOCRATIC SYSTEM IN INDONESIA
}

\begin{abstract}
The principle of a democracy country is by upholding the constitution and ideology of the country. The independency in social and political rights becomes a warranty to achieve a country that upholds the democracy; hence, people's aspiration can be well-delivered. The problem is that how the principle and warranty of the citizens' rights according to the 1945 Constitution and how the social political dynamic in democratic system in Indonesia. It applies normative juridical research. It is included in literature research which is a research on primary and secondary legal materials consisting of laws and regulations and related literatures in order to solve the legal problems or the discussed problems. The independency to deliver the opinion in public must be conducted with responsibility along with the provisions of the applicable laws and regulations. Therefore, the government should manage and control the domination of capitalist climate thus it still walks on the corridor that will not harm the people. The government should also open and empower public room optimally as the people's instruments in delivering their aspirations, and close any possibilities of money politic to perform either by political elites or communities. By leaving the money politic occurs, it will not only affect the corrupt politicians and curb people's consciences in giving their political participation, but also harm the democratic election.

Keywords: Social-Political Rights; Participation; Democracy
\end{abstract}




\section{PENDAHULUAN}

\section{A. Latar Belakang}

Prinsip

demokrasi

mengandung arti dijunjung tingginya hak setiap orang untuk berpendapat, untuk memiliki ideologi tertentu, dan untuk memiliki identitas tertentu serta menghargai setiap pendapat yang keluar dari pikiran setiap orang. ${ }^{1}$ Konsep demokrasi menjadi sebuah kata kunci tersendiri dalam bidang ilmu politik. Prinsip semacam trias politica ini menjadi sangat penting untuk diperhitungkan ketika fakta-fakta sejarah mencatat kekuasaan pemerintah (eksekutif) yang begitu besar ternyata tidak mampu untuk membentuk masyarakat yang adil dan beradab, bahkan kekuasaan absolut pemerintah seringkali menimbulkan pelanggaran terhadap hak-hak asasi

manusia.Kebebasanberpendapat atau mengemukakan pendapat merupakan hak untuk setiap WNI yang dijamin oleh UUD 1945, bahkan hak kebebasan berpendapat menempati kedudukan yang paling tinggi dalam aas-asas demokrasi dan liberalisasi, hanya saja hak tersebut tetap ada koridor atau batasan hukumnya. ${ }^{2}$ Keberadaan

${ }^{1}$ Nuraini Latuconsina, "Perkembangan Demokrasi dan Civil Society di Indonesia", Jurnal Populis Vol. 7 Nomor 2, Oktober 2013, Universitas Pattimura Ambon. Hal 1, diakses 4 Juli 2019 Pukul 14.13.

2Jailani, SH.,MH, "Sistem Demokrasi di Indonesia ditinjau Dari Sudut Hukum Tata Negara", Jurnal Inovatif Vol. 8 Nomor 1, Januari 2015, Hal 1, diakses 4 Juli 2019 Pukul 13.35. hak asasi manusia dalam konsepsi negara hukum dalam demokrasi di Indonesia suatu hal yang paling mendasar. Namun konsepsi pengaturan hak asasi manusia oleh negara tersebut bukan berarti terjadinya pengekangan hak asasi manusia oleh negara, namun dalam konsepsinya adalah pengaturan oleh negara, karena Implementasi demokrasi dan Hak asasi manusia yang berkedaulatan rakyat merupakan cita-cita yang hendak dicapai.

Keberadaan hukum dan negara dalam konsepsi negara hukum merupakan dua sisi yang tidak dapat dipsahkan antara satu dengan yang lainnya. Hal ini di karenakan suatu negara yang mengkultuskan sistem ketatanegaraannya sebagai negara hukum tentunya tidak dapat dipisahkan dari eksistensi hukum dalam penyelenggaraan negara dan pemerintahan di negara tersebut. Negara hukum merupakan konsep bernegara yang telah berkembang dari beberapa dekade lalu. Terbukti dari keberadaan pemikiran mengenai konsep-konsep negara hukum yang telah ada dan berkembang jauh sebelum konsep negara hukum telah tersusun dan tertata seperti saat sekarang ini. Indonesia adalah negara hukum, dimana terdapat dalam Pasal 1 ayat (3) Undang-Undang Dasar Negara Republik Indonesia(UUD NRI) Tahun 1945 yang mengatur bahwa Negara Indonesia adalah negara hukum. Menurut Jimly Asshiddiqie, "Indonesia diidealkan dan dicita-citakan oleh the founding fathers sebagai suatu 
negara hukum (Rechtsstaat/The Rule of Law)". Begitu pula dengan keberadaan Hak Asasi Manusia dalam konsepsi negara hukum tersebut. Namun konsepsi pengaturan hak asasi manusia oleh negara tersebut bukan berarti terjadinya pengekangan hak asasi manusia oleh negara, namun dalam konsepsinya adalah pengaturan oleh Negara. Berkaitan dengan hal tersebut menurut Bahder Johan Nasution bahwa dilihat dari sudut pandang pengaturan hak asasi manusia, pada satu sisi hak asasi memiliki sifat dasar yang membatasi kekuasaan pemerintahan, namun sebaliknya pada sisi lain pemerintah diberi wewenang untuk membatasi hak-hak dasar sesuai dengan fungsi pengendalian (sturing). Jadi walaupun hak-hak dasar mengandung sifat membatasi kekuasaan pemerintahan, pembatasan tersebut tidak berarti mematikan kekuasaan pemerintahan yang pada dasarnya berisi wewenang untuk mengendalikan kehidupan masyarakat. $^{3}$

Sebagai ide, demokrasi bukan hal baru melainkan telah melalui proses panjang, bahkan dinilai sebagai salah satu bentuk pemerintahan. Menurut Aristoteles, demokrasi merupakan produk dari perubahan bentuk pemerintahan yang dimulai dari

${ }^{3}$ Fauzan Khairazi, SH.,MH, "Implementasi Demokrasi dan Hak Asasi Manusia di Indonesia", Jurnal Inovatif Vol. 3 Nomor 1, Januari 2015. Hal 1-2, diakses 10 Juli 2019, Pukul 14.30 . monarki, kemudian berubah menjadi tirani. Dari tirani berubah menjadi aristokrasi, kemudian oligarki. Oligarki digantikan oleh polity, yang kemudian menjadi demokrasi. ${ }^{4}$ Sedangkan menurut Schumpeter, demokrasi atau metode demokratis adalah prosedur kelembagaan dalam mencapai keputusan politik, sehingga individu-individu yang bersangkutan dapat memperoleh kekuasaan untuk membuat suatu keputusan melalui perjuangan yang kompetitif dalam rangka memperoleh suara rakyat. Peran rakyat dalam hal ini tidaklah memerintah, namun hanya sebagai pemilih dan peran para pemilih bukan memutuskan masalah-masalah politik, tetapi untuk memilih orang-orang yang akan membuat keputusankeputusan bagi mereka. ${ }^{5}$

Istilah demokrasi pada dua dasawarsa terakhir, khususnya di berbagai negara berkembang kian populer, baik pada tingkat wacana maupun aras gerakan sosial politik. Sebagai suatu sistem politik, demokrasi telah menempati stratum teratas yang diterima oleh banyak negara karena dianggap mampu mengatur

${ }^{4}$ Gonda Yumitro, "Partai Islam dalam Dinamika Demokrasi di Indonesia”. Jurnal Ilmu Sosial dan Ilmu Politik Volume 17 Nomor 1, Juli 2013. Hal 3, diakses tanggal 10 Juli 2019, Pukul 14.45.

${ }^{5}$ Muhammad Hanafi, "Kedudukan Musyawarah Dan Demokrasi Di Indonesia”. Jurnal Cita Hukum Vol. 1 Nomor 2, Desember 2013. Fakultas Syariah dan Hukum UIN Syarif Hidayatullah Jakarta, Hal 8-9, diakses tanggal 10 Juli 2019, Pukul 14.10. 
dan menyelesaikan hubungan sosial dan politik, baik yang melibatkan kepentingan antar individu dalam masyarakat, hubungan antar masyarakat, masyarakat dan negara maupun antar negara di dunia. Kesantunan politik harus tetap dijaga dalam demokrasi. Konsep liberalisasi yang melekat pada ideologi demokrasi mesti diartikan sebagai sebuah masyarakat yang bebas dan bertanggung jawab, yaitu masyarakat yang memiliki aturan main yang jelas sehingga si kuat tidak menindas si lemah. Ini dapat terjadi kalau ada hukum yang mengatur segala bentuk permainan, baik politik, ekonomi, dan kebudayaan. Aturan main itu hendaknya menjamin pemberian ruang gerak atau kesempatan yang sama bagi setiap warga negara untuk melakukan aktifitas kehidupannya. Aturan main yang sudah dirumuskan dan dituangkan dalam bentuk hukum tersebut seyogyanya dihormati oleh setiap aktor sosial dalam segala tingkat dan kapasitas. Dengan kata lain, baik itu penguasa, pemerintah, pengusaha dan rakyat kebanyakan semuanya harus hormat dan tunduk pada hukum (aturan main). Barang siapa yang menyimpang dari aturan main atau barang siapa yang mencoba memanipulasi aturan main dapat ditindak melalui lembaga peradilan tanpa pandang bulu. ${ }^{6}$

${ }^{6}$ Heru Nugroho, "Demokrasi dan Demokratisasi : Sebuah Kerangka Konseptual Untuk Memahami Dinamika Sosial-Politik Di Indonesia”, Jurnal Pemikiran Sosiologi Vol. 1 Nomor 1,
Demokrasi dan kebebasan sering diasumsikan sebagai dua hal dalam satu paket. Mendapatkan demokrasi "pasti" mendapatkan pula kebebasan. Sedangkan pada sisi yang lain, demokrasi dan kebebasan terkadang masih menemui banyak persoalan dalam pelaksanannya, terutama yang berkaitan dengan kebebasan warga negara, sementara kebebasanpun hanya bisa didapat atau diperoleh bila ada demokrasi dan konstitusi yang menjaminnya. Hakikat dari demokrasi tidaklah bisa menjamin kebebasan secara mutlak, perlu ada komitmen untuk membangun tradisi kebebasan, tradisi diantara semua warga yang diwujudkan dalam aturan serta penegakan hukum yang tegas, bahwa setiap orang bebas berbicara dan menyalurkan pendapatnya. Di Indonesia itu sendiri belum mencapai pada tahapan pelaksanaan demokrasi yang substansial, yaitu sikap-sikap dari perilaku warga negara demokratis. Hal ini tampak bukan hanya pada masyarakat itu sendiri, tetapi juga pada pemerintah, karena itu tidak mengherankan, salah satu contoh, jika keributan pada pelaksanaan Pilkada masih sering mewarnai proses demokrasi di Indonesia. Di samping itu, tingkat nasionalitas politik masyarakat pada umumnya dinilai masih rendah karena demokrasi substansial belum dilaksanakan dengan baik. Kiranya hal ini dapat mengindikasikan jalan panjang

Mei 2012. Hal 1,diakses Tanggal 4 Juli 2019 Pukul 14.00. 
demokrasi Indonesia masih penuh dengan hambatan dan tantangan justru dari efek demokrasi itu sendiri. Hal ini tampak bukan hanya pada masyarakat itu sendiri, tetapi juga pada pemerintah, karena itu tidak mengeherankan, salah satu contoh, jika keributan pada pelaksanaan Pilkada masih sering mewarnai proses demokrasi di Indonesia. Di samping itu, tingkat nasionalitas politik masyarakat pada umumnya dinilai masih rendah karena demokrasi substansialbelum dilaksanakan dengan baik. Kiranya hal ini dapat mengindikasikan jalan panjang demokrasi Indonesia masih penuh dengan hambatan dan tantangan justru dari efek demokrasi itu sendiri. $^{7}$

\section{B. Perumusan Masalah}

1. Bagaimana Prinsip Dan Jaminan Hak Warga Negara Menurut UUD 1945 ?

2. Bagaimana Dinamika Sosial Politik Dalam Sistem Demokrasi di Indonesia ?

\section{Metode Penelitian}

Untuk menjawab permasalahan yang telah dirumuskan dalam penulisan ini, maka metode penelitian yang digunakan berupa penelitian hukum yuridis normatif yang merupakan penelitian kepustakaan, yaitu penelitian terhadap bahan hukum primer dan bahan hukum sekunder yang terdiri dari peraturan perundangundangan dan literatur-literatur terkait untuk memecahkan

\footnotetext{
${ }^{7}$ Jailani, SH.,MH, “Sistem

Demokrasi di Indonesia ditinjau Dari

Sudut Hukum Tata Negara”, Jurnal

Inovatif Vol. 8 Nomor 1, Januari 2015,

Hal 1-2, diakses 4 Juli 2019 Pukul 13.35.
}

persoalan hukum atau permasalahan yang akan dibahas.

II. PEMBAHASAN

Prinsip dan Jaminan Hak Warga Negara Menurut UUD 1945

Sebagai negara demokrasi kebebasan berpendapat tidak harus menjadi sekedar bebas mengemukakan pendapat tetapi harus bertanggung jawab dan beretika dalam berpendapat. Menentukan parameter nilai etika dalam berpendapat yang ideal sangat sulit. Setiap upaya penentuan batas nilai etika berpendapat akan divonis sebagai pengebirian berpendapat. Bahkan undang-undang baru seperti Undang-undang Informasi dan Transaksi Elektronik (UU ITE) yang diciptakan oleh para ahli hukum dan pendekar demokrasi saja dianggap mengkebiri kebebasan berpendapat. Etika berpendapat tersebut tidak perlu harus sesuai dengan etika adat ketimuran atau etika kesopanan. Tetapi layaknya dalam berpendapat harus sesuai dengan fakta yang sebenarnya tanpa harus men"justifikasi" fakta yang masih belum jelas. Artinya, dalam kebebasan berpendapat tidak boleh memutarkan balikkan fakta kebenaran yang ada. Bila hal ini terjadi akan merupakan fitnah dan pencemaran nama baik. Bila etika berpendapat hanya melanggar etika adat, budaya dan kesopanan tidak terlalu masalah karena sangsi yang didapat hanyalah sekedar sanksi sosial. Kebebasan berpendapat/mengemukakan pendapat merupakan hak untuk setiap WNI yang dijamin oleh 
UUD 1945, bahkan hak kebebasan berpendapat menempati kedudukan yang paling tinggi dalam aas-asas demokrasi dan liberalisasi, hanya saja hak tersebut tetap ada koridor atau batasan hukumnya. Ada juga yang penyalurannya lewat lembaga perwakilan di DPR atau DPRD dan hak kebebasan berpendapat tidak boleh melanggar daripada hak-hak orang lain karna pada dasarnya setiap warga negara memiliki hak kebebasan berpendapat yang posisinya sama. Penggunakan hak mengemukakan pendapat yang dianut negara kita, kita harus memegang prinsip bebas dan bertanggung jawab. Bebas artinya, bahwa segala ide, pikiran atau pendapat, dapat dikemukakan secara bebas tanpa ada tekanan dari siapapun juga. Sedangkan bertanggung jawab artinya, bahwa ide, pikiran atau pendapat tersebut mesti dilandasi oleh akal sehat, niat baik dan norma-norma yang berlaku. $^{8}$ Untuk itu setiap masyarakat harus mampu menyaring informasi dan berita yang masuk dan mencari tahu kebenarannya. Hal ini sebagai bentuk penyeimbang dan penetralisir dengan arus informasi yang begitu derasnya dibalik tantangan kondisi demokrasi Indonesia. Upaya yang dilakukan juga sebagai menjaga persatuan dan kesatuan bangsa Indonesia yang tidak mudah dipecah belah

\footnotetext{
${ }^{8}$ Jailani, SH.,MH, "Sistem

Demokrasi di Indonesia ditinjau Dari

Sudut Hukum Tata Negara”, Jurnal

Inovatif Vol. 8 Nomor 1, Januari 2015,

Hal 7, diakses 4 Juli 2019 Pukul 13.35.
}

dengan adanya oknum penyebar informasi palsu. ${ }^{9}$

Tentunya

upaya

demokratisasi dan kebebasan warga gegara tersebut harus terus dilakukan pembenahan dan penyempurnaan dalam menyeimbangkan dan menyelaraskan dengan tututan demokrasi secara kontemporer. Hal ini dikarenakan kebutuhan atas konsepsi demokrasi tersebut dari waktu ke waktu memang harus selalu disesuaikan dengan kebutuhan kekinian yang berbasis kepada kepentingan Negara dan warga Negara dan menciptakan konsep demokrasi dan kebebasan warga Negara ke depan. ${ }^{10}$

Demokrasi memberikan pemahaman, bahwa dari sebuah kekuasaan dari rakyat. Dengan pemahaman seperti itu, rakyat akan melahirkan sebuah aturan yang menguntungkan dan melindungi hak-haknya. Agar itu bisa terlaksana, diperlukan sebuah peraturan bersama yang mendukung dan menjadi dasar pijakan dalam kehidupan bernegara untuk menjamin dan melindungi hak-hak rakyat. Dalam konteks Indonesia

\footnotetext{
${ }^{9}$ Wahyuningtyas Dwi Saputri, Bagus Edi Prayogo, "Tantangan Demokrasi di Era Globalisasi Demi Mewujudkan Pencegahan Politik Uang Dalam Pemilu”, Jurnal Vol. 4 Nomor 2 Tahun 2018, Fakultas Hukum Universitas Negeri Semarang. Hal 3, diakses tanggal 10 Juli 2019, Pukul 14.50 .

${ }^{10}$ Fauzan Khairazi, SH.,MH, "Implementasi Demokrasi dan Hak Asasi Manusia di Indonesia”, Jurnal Inovatif Vol. 3 Nomor 1 Januari 2015. Hal 4, diakses 10 Juli 2019, Pukul 14.30.
} 
Konstitusi yang menjadi pegangan adalah UUD 1945, jika dicermati, UUD 1945 mengatur kedaulatan rakyat dua kali, pertama pada pembukaan alinea keempat, "maka disusunlah kemerdekaan kebangsaan Indonesia itu dalam suatu Undang-Undang Dasar Negara Indonesia yang berkedaulatan rakyat, "Kedua, pada pasal 1ayat (2) UUD 1945 hasil perubahan berbunyi, Kedaulatan berada di tangan rakyat dan dilaksanakan menurut undang-undang dasar". Dengan demikian, UUD 1945 secara tegas mendasar pada pemerintahan demokrasi karena berasaskan kedaulatan rakyat. ${ }^{11}$

Kemerdekaan

menyampaikan pendapat di muka umum harus dilaksanakan dengan bertanggung jawab, sejalan dengan ketentuan peraturan perundang-undangan yang berlaku, pasal 28 UUD 1945 serta amandemen yang sudah empat kali dilakukan serta prinsip hukum internasional sebagaimana yang tercantum dalam pasal 29 deklarasi universal HAM dekrit 1949 yang berlaku secara universal di dunia, termasuk Indonesia. Berdasarkan UndangUndang Nomor 9 tahun 1998 tentang kebebasan menyampaikan pendapat di muka umu, terdapat lima asas, yang merupakan landasan kebebasan bertanggung jawab dan bertindak untuk

\footnotetext{
${ }^{11}$ Cora Elly Noviati, "Demokrasi dan Sistem Pemerintahan”, Jurnal Konstitusi Vol. 10 Nomor 2, Juni 2013. Hal 1,diakses Tanggal 10 Juli 2019, pukul 14.40.
}

menyampaikan pendapat di muka umum, yaitu : ${ }^{12}$

1) Asas keseimbangan antara hak dan kewajiban;

2) Asas musyawarah dan mufakat;

3) Asas kepastian hak dan keadilan;

4) Asas proporsionalitas;

5) Asas mufakat.

Warga negara yang menyampaikan pendapat di muka umum berkewajiban dan bertanggung jawab untuk :

1) Menghormati hak-hak dan kebebasan orang lain;

2) Menghormati aturan-aturan moral yg diakui umum;

3) Mentaati hukum dan peraturan yang berlaku;

4) Menjaga keamanan dan ketertiban umum;

5) Menjaga keutuhan persatuan kesatuan bangsa

Ada beberapa hal yang harus diperhatikan dalam mengemukakan pendapat secara bebas dan bertanggung jawab, yaitu :

1) Pendapat yang dikemukakan serta argumentasi yang kuat dan masuk akal sehingga tidak sembarangan berpendapat;

2) Pendapat hendaknya mewakili kepentingan orang banyak sehingga bermanfaat bagi kehidupan bersama; 
3) Pendapat dikemukakan dalam kerangka aturan yang berlaku, sehingga tidak melanggar hak;

4) Orang yang brpendapat harus terbuka dan siap menerima kritik dan saran dari orang lain;

5) Penyampaian pendapat hendaknya dilandasi oleh suatu keninginan dan kebaikan bersama untuk mengembangkan nilai-nilai keadilan dan demokrasi

Tetapi warga negara bebas mengungkapkan pendapat asal tidak bertentangan dengan falsafat yakni pancasila, UUD 1945, dan tujuan Negara Republik Indonesia.

\section{Dinamika Sosial Politik Dalam} Sistem Demokrasi di Indonesia Ide negara demokrasi bukanlah hal yang baru bagi Indonesia karena sejaknegara ini berdiri, ide utama yang diajukan dalam penyelenggaraan pemerintahan dan pola hubungan pemerintah-rakyat sudah didasarkan pada konsep demokrasi. Namun demokrasi yang dimaksud ialah sebuah model demokrasi yang bukan liberal, melainkan terikat dengan nilai bangsa.Ide demokrasi Indonesia sebagaimana yang digariskan founding fathers, demokrasi Indonesia yang berintikan mass protect atau sikap kritis rakyat terhadap penguasa, musyawarah untuk mencapai mufakat dan tolong menolong. Demokrasi yangdilaksanakan melalui prosedur-prosedur berdasarkan hukum serta dijiwai oleh pancasila, sebagai landasan kefilsafatan dan norma kritik bagi Tata Hukum Indonesia. ${ }^{13}$

Sebaliknya dengan suatu negara yang menjalankan konsepsi demokrasi sosial dituntut untuk menawarkan perlindungan sosial pada warganya dari kemungkinan terjadinya pelanggaran hak asasi. Disamping itu, negara juga harus mampu memberikan jaminan pada warganya supaya berkesempatan memperoleh dan menikmati fasilitas pendidikan yang memadai. Warga masyarakat tidak hanya sekedar dimungkinkan memperoleh keterampilan, tetapi juga diarahkan agar dapat turut ambil bagian dalam dinamika kehidupan kebudayaan yang lebih luas. Tidak kalah pentingnya, bagi negara yang menjalankan konsep demokrasi sosial harus dapat menjaga harkat dan martabat warganya dalam konteks ekonomi dan sosial. Oleh karena itu negara wajib dapat mengelola dan mengendalikan dominasi iklim kapitalis agar tetap berjalan pada koridor yang tidak merugikan warga. Negara juga harus membuka dan memberdayakan ruang publik secara optimal sebagai instrumen warga dalam menyalurkan aspirasinya (Myron Weiner, 1987). Konsep demokrasi sosial menuntut setiap

${ }^{13}$ Zulkarnain Ridlwan, "Cita Demokrasi Indonesia dalam Politik Hukum Pengawasan Dewan Perwakilan Rakyat terhadap Pemerintah", Jurnal Konstitusi Vol. 12 Nomor 2, Juni 2015, Fakultas Hukum Universitas Lampung. Hal 23,diakses Tanggal 10 Juli 2019, Pukul 14.15 . 
negara yang mempraktekkannya agar selalu memiliki jaminan sosial atas warganya secara menyeluruh. Jaminan sosial itu harus mampu memberikan perlindungan atas hak-hak dasar yang semestinya dimiliki oleh semua individu sebagai warga negaranya. Negara diwajibkan untuk dapat mempertahankan sebuah penyebaran kesempatan hidup yang adil. Negarapun dituntut harus mampu memberikan jaminan keberhasilan atas pertumbuhan ekonomi serta kohesi sosial dan kestabilan politik. Pada kondisi terdapat ketidakstabilan sosial, politik dan ekonomi negara harus mampu meredam goncangan itu agar tidak berlarut-larut. Negara juga harus dapat memberikan rasa aman bagi warganya dari kondisi ketidakberdayaan akibat dominasi sistem kapitalisme pasar. ${ }^{14}$

Diskursus ketatanegaraan tidak dapat dilepaskan dari pembahasan mengenai bangunan demokrasi. Keberadaan Dewan Perwakilan Rakyat di Indonesia dengan fungsi pengawasannya terhadap pemerintah merupakan salah satu wujud demokrasi. Sebagai negara yang telah memilih prinsip demokrasi dan dipadukan dengan prinsip negara hukum, Indonesia akan menata tertib hidup dan kehidupan dalam bermasyarakat, berbangsa dan

\footnotetext{
${ }^{14}$ Heru Nugroho, "Demokrasi dan Demokratisasi : Sebuah Kerangka Konseptual Untuk Memahami Dinamika Sosial-Politik Di Indonesia”, Jurnal Pemikiran Sosiologi Vol. 1 Nomor 1, Mei 2012. Diakses Tanggal 4 Juli 2019 Pukul 14.00.
}

bernegara menggunakan aturan hukum yang demokratis. Bangsa Indonesia akan membangun tatanan kehidupan bersama dalam wadah negara Indonesia yang demokratis dan didasarkan pada aturan hukum. Artinya, bangsa Indonesia akan meletakkan prinsip demokrasi dan prinsip hukum sebagai suatu sinergi yang saling bersimbiose-mutualistik dalam mewujudkan adanya national legal order yang demokratis dalam negara. Pembentukan undang-undang adalah bagian dari aktivitas dalam mengatur masyarakat yang terdiri dari atas gabungan individuindividu manusia dengan segala dimensinya, sehingga merancang dan membentuk undang-undang yang dapat diterima masyarakat luas merupakan suatu pekerjaan yang sulit. Kesulitan ini terletak pada kenyataan bahwa kegiatan pembentukan undang-undang adalah suatu bentuk komunikasi antara lembaga yang menetapkan yaitu pemegang kekuasaan legislatif dengan rakyat dalam suatu negara. Berbagai kesulitan dalam pembentukan undangundang tersebut, tampaknya telah lama dirasakan oleh bangsa Indonesia sebagai negara yang sedang berkembang. Kesulitankesulitan dalam pembentukan undang-undang ini, sekarang lebih dirasakan oleh bangsa Indonesia yang tengah menghadapi berbagai problem sosial secara mendasar pada permasalahan struktural dan kultural yang multi dimensi. Pembentukan undang-undang ini sekarang dan di masa yang akan datang akan terus mengalami 
peningkatan sebagai respon atas tuntutan masyarakat seiring dengan bertambah kompleksnya perkembangan dan kondisi masyarakat. Pembentukan hukum akan mengikuti struktur sosialpolitik dari masing-masing negara. Bagi negara yang menganut konfigurasi politik otoriter, maka pembentukan hukumnya akan memperlihatkan ciri yang otoritarian juga. Sedangkan manakala proses pembentukan hukum (legislasi) tersebut ditempatkan dalam konteks struktur sosial-politik dari negara demokrasi, niscaya di dalamnya akan terjadi kompromi dari konflik-konlik nilai dan kepentingan yang berbeda-beda dalam masyarakat. ${ }^{15}$

Ciri sebuah negara demokratis adalah seberapa besar negara melibatkan masyarakat dalam perencanaan maupun pelaksanaan pemilihan umum. Sebab partisipasi politik masyarakat (pemilih) merupakan aspek penting dalam sebuah tatanan negara demokrasi. Hubungannya dengan demokrasi, partisipasi politik berpengaruh terhadap legitimasi oleh masyarakat terhadap jalannya suatu pemerintahan. Pelaksanaan pemilu misalnya partisipasi politik berpengaruh terhadap legitimasi masyarakat kepada calon atau

\footnotetext{
${ }^{15}$ Putera Astomo, "Pembentukan Undang-Undang Dalam Rangka Pembaharuan Hukum Nasional Di Era Demokrasi”.Jurnal Konstitusi, Volume 11, Nomor 3, September 2014. Universitas Sulawesi Barat (UNSULBAR), Hal 2-3, diakses tanggal 10 Juli 2019, Pukul 15.00.
}

pasangan calon yang terpilih. Setiap masyarakat memiliki referensi dan kepentingan masingmasing untuk menentukan pilihan mereka dalam pemilu. Bisa dikatakan bahwa masa depan pejabat publik yang terpilih dalam suatu pemilu tergantung pada preferensi masyarakat sebagai pemilih. Tidak hanya itu, partisipasi politik masyarakat dalam pemilu dapat dipandang sebagai evaluasi dan kontrol masyarakat terhadap pemimpin atau pemerintahan. Oleh karena itu upaya meningkatkan partisipasi politik masyarakat harus didasarkan pada analisis dan argumentasi yang kuat. Hal ini disebabkan adanya kebutuhan untuk mewujudkan langkah strategis dalam meningkatkan kuantitas dan kualitas partisipasi politik masyarakat dalam pemilu dan penyempurnaan sistem pemilu yang lebih baik kedepan. Itu artinya argumentasi dan analisis yang lahir mesti berbasis pada : pertama, metodologi atau kerangka pikir yang tepat untuk memahami dinamika partisipasi politik, serta kedua, didasari dengan kepekaan yang kuat terhadap dinamika-dinamika yang berkembang dalam wilayah ekonomi, administrasi, politik, serta sosial dan kultural. ${ }^{16}$

${ }^{16}$ Daud M. Liando, "Pemilu Dan Partisipasi Politik Masyarakat (Studi Pada Pemilihan Anggota Legislatif Dan Pemilihan Presiden Dan Calon Wakil Presiden Di Kabupaten Minahasa Tahun 2014)”. Jurnal LPPM Bidang EkoSosBudKum, Volume 3 Nomor 2 Tahun 2016Edisi Oktober, Fakultas Ilmu Sosial dan Ilmu Politik Universitas Sam 
Di setiap zaman dan tempat, rakyat selalu bertujuan ingin mencapai kehidupan yang lebih baik, kehidupan yang bebas dari berbagai tirani sosial. Betapapun seseorang telah mempunyai kekayaan, sedang disekitarnya terdapat orang-orang yang jauh lebih kaya dari dia dan memiliki kemudahan akses di pelbagai bidang, hal ini akan memunculkan perasaan kekurangan (inferior), dan merasa adanya tirani sosial. Karena perasaan kekurangan tersebut sudah sangat cukup untuk membuatnya hidup dalam kecemasan dan kemuraman. Sehingga dapat disimpulkan bahwa tujuan rakyat adalah menciptakan keadaan dimana mereka bisa hidup tanpa kecemasan dan kemuraman. Dalam menciptakan keadaan yang seperti itu, mereka melawan keadaan tiranik yang terdapat didalamnya. Yaitu keadaan yang mempermudah kelompok tertentu dalam masyarakat untuk meraih hidup "makmur dan terhormat". Untuk menghadapi keadaan yang seperti ini, apakah demokrasi politik dapat mewujudkan tujuantujuan rakyat?. Tampaknya harus diakui bahwa demokrasi politik adalah demokrasi bagi para penguasa dan orang-orang kaya. Namun hal tersebut bisa jadi tidak, jika dilihat dari sisi lain, demokrasi politik merupakan sarana yang jika digunakan dengan baik akan banyak membantu menyingkap hakikat

Ratulangi Manado. Hal 2, diakses tanggal 13 Juli 2019. masalah sosial, seperti kemiskinan, ketertindasan, biaya pendidikan yang mahal, kesehatan dan lain sebagainya. Demokrasi politik yang mengklaim mampu memperkuat dan menancapkan kebebasan publik akan dapat memberikan banyak peluang untuk membuka pikiran rakyat terhadap hakikat konflik sosial. Demokrasi politik merupakan sarana yang niscaya bagi penyadaran rakyat. Adanya parlemen, partai-partai dan kebebasan pers serta masa-masa pemilu, merupakan peluangpeluang dan kemungkinankemungkinan yang disediakan oleh demokrasi politik dalam rangka menyadarkan rakyat dan mengarahkan pada perjuangan akan hak-hak mereka. Penyadaran rakyat tersimpul pada upaya memberikan pengertian bahwa solusi yang tepat bagi masalah sosial ini terletak pada upaya mengubah keadaan yang merugikan mereka. Kesejahteraan para petani, misalnya, tidak akan terwujud, taken for granted, dengan perpindahan mereka ke barisan para pemilik tanah, karena memang tidak mungkin mencapainya. Kalaupun berhasil, hal tersebut tercapai dengan mengorbankan banyak petani lainnya. Begitu pula para buruh, mereka tidak bisa mencapai kesejahteraan hidup hanya dengan cara memperbaiki upah mereka. Karena meskipun hal itu terpenuhi, mereka akan tetap tereksploitasi dan kekurangan. Persoalannya bukan masalah upah, melainkan keadaan sosial dan pengaturan kehidupan 
masyarakat. Kaum tertindas harus memahami, bahwa demokrasi yang sesungguhnya, keadilan sosial dan persamaan tidak akan terwujud kecuali dengan perjuangan, satu perjuangan yang terarah pada tujuan. Dari sini semakin jelas bahwa tugas ini tidak akan dapat dilaksanakan kecuali dalam naungan kebebasan publik. Di sinilah tampak hubungan antara demokrasi politik dan demokrasi sosial. Hubungan yang bersifat dialektik. Demokrasi sosial tidak akan terwujud kecuali dalam lingkungan demokrasi politik, dan yang terakhir tidak akan terwujud dengan murni dan bersih kecuali dalam keadaan-keadaan yang dikuasai demokrasi sosial. Perjuangan kelas tertindas semestinya memperjuangkan untuk kebebasan publik, yakni demokrasi politik sebagai sarana, dan demokrasi sosial sebagai tujuan. ${ }^{17}$

Pemilu adalah salah satu cara untuk menentukan arah perjalanan bangsa sekaligus menentukan siapa yang paling layak untuk menjalankan kekuasaan pemerintahan negara tersebut (Sardini 2011:298). Pemilu merupakan proses pemilihan pemimpin bangsa dan merupakan wujud dari kedaulatan rakyat. Pemilu juga merupakan proses pemberian hak kepada

\footnotetext{
${ }^{17}$ Heri Kusmanto, "Partisipasi Masyarakat Dalam Demokrasi Politik”. Jurnal Ilmu Pemerintahan dan Sosial Politik Vol 2 Nomor 1 Tahun 2014. Fakultas Ilmu Sosial dan Ilmu Politik, Universitas Sumatera Utara. Hal 9, diakses tanggal 13 Juli 2019.
}

rakyat untuk ikut serta dalam menentukan haluan negara dengan memilih wakil-wakilnya di dalam DPR atau gedung dewan secara berkala. Pemilu yang sehat adalah pemilu yang jujur, terbuka dan tanpa ada tekanan politik maupun psikologis dari orang lain. Perlu diketahui bahwa terkadang pemilu merupakan ajang pesta oleh para pemilik modal untuk memperoleh statusnya menjadi seorang dewan dengan cara mempengaruhi pemilih dalam hal ini masyarakat melalui berbagai macam cara, baik itu berupa pemberian uang dan imbalan dan sebagainya, namun juga dalam bentuk tekanan politik dan bahkan tidak jarang menggunakan tekanan fisik. Tidak bisa ditampik sebuah kenyataan bahwa prinsip dari rakyat, oleh rakyat dan untuk rakyat sangat tidak berlaku apabila melihat kenyataan pemilihan umum di Indonesia. Masyarakat tidak lagi sebagai penentu dari bangsa dan negara ini, namun rakyat hanya menjadi objek politik dari beberapa elit yang ingin menjadi seorang pemimpin yang bertujuan untuk memperoleh strata sosial yang lebih tinggi bahkan mencari keuntungan. Secara teoritis, politik merupakan upaya untuk berperan serta dalam mengurus dan mengendalikan urusan masyarakat atau orang banyak. Karena menyangkut kepentingan banyak orang, maka memang pada dasarnya politik sangat dekat dengan kekuasaan. Di sisi lain, karena politik berusaha mengurus dan mengendalikan urusan masyarakat, politik juga dapat dijadikan sarana untuk 
menyampaikan kebaikan dan kebenaran kepada masyarakat luas. Namun karena kenyataan yang ada, banyak yang sering melihat politik sebagai seni atau ilmu dimana praktek-praktek yang cerdik dan terkadang tidak jujur harus digunakan dalam persaingan dengan orang lain untuk memproleh kekuasaan dan kepemimpinan ditengah-tengah masyarakat. Hal ini bukan tidak berdasar lagi, sebab banyak para calon anggota legislatif atau sering di sebut caleg sering menggunakan intrik-intrik politik yang sangat licik bahkan tidak bisa di terjemahkan oleh aparat yang bertugas mengawasi berjalanya pemilu. Hal yang sangat marak terjadi dan sering dilakukan adalah politik uang. Politik uang ini merupakan wujud dari para elit politik yang melakukan cara yang tidak fair dalam memperoleh kekuasaan. Karena tentu saja calon-calon yang memiliki modal yang banyak akan memiliki kesempatan yang besar untuk terpilih menjadi pemimpin atau wakil rakyat. Hal ini tidak dapat dipungkiri bahwa dengan melakukan politik uang maka akan meningkatkan popularitas dari seorang kandidat, betapa tidak, karena image yang terbangun di masyarakat bahwa mereka sangat mewajarkan seseorang mencalonkan diri sebagai wakil rakyat karena kaya atau memiliki uang yang sangat banyak dibandingakan dengan orang yang mempunyai modal politik yang minim. ${ }^{18}$

\footnotetext{
${ }^{18}$ Dendy Lukmajati, “Praktek Politik Uang
}

Asas jujur dan adil (Jurdil)
maupun asas Pemilu Bersih
(Luber) dalam Pemilihan Kepala
Daerah (Pilkada) maupun

Pemilihan Umum (Pemilu) secara umum hanyalah sebuah slogan belaka, karena pada dasarnya Money Politics merupakan sebuah sistem yang tidak akan pernah hilang dalam proses demokrasi Indonesia dan hal ini akan terus menerus terjadi dan dilakukan oleh para calon dan Jurkam serta Timses masing-masing calon dalam pilkada dan pemilu guna mencari perhatian serta suara dari para calon pemilih untuk memenangkan mereka dalam pilkada maupun pemilu. Walaupun adanya partai politik yang berasaskan Islam akan tetapi praktek Money Politics ini tetap ada walau dikemas dalam agenda yang sangat rapi. Akan tetapi juga ada juga partai politik yang memang benar-benar mereka tidak melakukan politik uang (Money Politics). Serta merebaknya Money Politics membawa implikasi yang sangat berbahaya bagi demokrasi dan penguatan negara bangsa. Melalui Money Politics kedaulatan bukan ada pada tangan rakyat akan tetapi kedaulatan berada ditangan "uang". Oleh karena itu, pemegang kedaulatan adalah "pemilik uang", baik dari dalam 
negeri maupun luar negeri dan bukan lagi rakyat mayoritas. ${ }^{19}$

Dunia seakan-akan tanpa batas, dengan mudahnya informasi masuk dan keluar. Hal ini mengakibatkan berbagai dampak baik positif maupun negatif. Dampak positif dari adanya globalisasi menambah wawasan pengetahuan tentang apa yang sedang terjadi didunia luar dan menambah semangat dalam melakukan berbagai inovasi yang bermanfaat seiring berjalannya kehidupan manusia. Dampak negatif dari globalisasi sendiri adalah semakin tingginya tingkat pemenuhan kebutuhan manusia. Dari pengaruh globalisasi tersebut dapat merubah tananan maupun struktur hingga kebiasaan dalam masyarakat jika tidak di filter dengan baik. Pengaruh tingginya tingkat pemenuhan kebutuhan manusia mengakibatkan banyak orang melakukan berbagai hal demi mecapai pemenuhan kebutuhan tersebut. Salah satu contoh yang sering terjadi dalam kehidupan demokrasi bangsa Indonesia adalah politik uang. Politik uang yang diterapkan segelintir orang yang mempunyai tujuan dan kepentingan pribadi, merupakan pelanggaran dalam hal berdemokrasi karena mencederai prinsip-prinsip dalam pemilu yang mempunyai asas rahasia, jujur, adil. Pesta demokrasi yang seharusnya diwarnai dengan

19 Roy Marthen, Marten Bunga, "Dampak Politik Uang Terhadap Demikrasi”. Jurnal UNNES Volume 4 Nomor 3 Tahun 2018, Fakultas Hukum Universitas Negeri Semarang. Hal 11, diakses tanggal 13 Juli 2019. sportivitas dan juga kejujuran tanpa ada paksaan dalam memilih wakil daerah. Ironisnya politik uang ini selalu menjadi cara ampuh untuk memenangkan salah satu wakil daerah dalam sebuah kontestasi politik. Masyarakat yang menjadi korban perlu adanya pengedukasian sehingga tidak terjadi politik uang dalam pesta demokrasi. $^{20}$

Politik uang yang meruyak. Akibat politik transaksional di antara elit politik dan para calon pejabat publik disertai penghamburan biaya politik yang amat berlebihan, akhirnya berlanjut dengan strategi instan "membeli suara publik" dan hal ini pada sisi lain dilihat sebagai kesempatan oleh sebagian publik untuk juga melibatkan diri dalam politik uang (money politics), baik untuk ikut serta dalam aneka acara kampanye dan pencitraan maupun untuk menawarkan pilihannya dalam suatu pemilihan umum maupun pemilihan calon kepala daerah. ${ }^{21}$

Elit politik maupun masyarakat perlu menyadari bahwa adanya praktik politik uang yang ada di Indonesia tentunya

\footnotetext{
${ }^{20}$ Wahyuningtyas Dwi Saputri, Bagus Edi Prayogo, “Tantangan Demokrasi di Era Globalisasi Demi Mewujudkan Pencegahan Politik Uang Dalam Pemilu”, Jurnal Vol. 4 Nomor 2 Tahun 2018, Fakultas Hukum Universitas Negeri Semarang. Hal 3, diakses tanggal 10 Juli 2019, Pukul 14.50 .

21 Ria Casmi Arrsa, "Pemilu Serentak dan Masa Depan Konsolidasi Demokrasi”. Jurnal Konstitusi, Volume 11 Nomor 3, September 2014, Universitas Brawijaya, Malang. Hal 8 diakes tanggal 10 Juli 2019, Pukul 15.00.
} 
dapat berdampak atau berimbas terhadap rusaknya tatanan demokrasi yang ada di Indonesia itu sendiri. karena politik uang dibiarkan tumbuh dengan subur dan didukung juga oleh kecenderungan masyarakat yang permisif. Selain itu juga dengan membiarkan politik uang tidak hanya berimpilkasi melahirkan politisi yang korup namun juga berakibat tercederainya suatu pemilu yang demokratis. $^{22}$

\section{KESIMPULAN}

Pembahasan yang ada dapat disimpulkan bahwa kemerdekaan menyampaikan pendapat di muka umum harus dilaksanakan dengan bertanggung jawab, sejalan dengan ketentuan peraturan perundang-undangan yang berlaku. Oleh karena itu negara wajib dapat mengelola dan mengendalikan dominasi iklim kapitalis agar tetap berjalan pada koridor yang tidak merugikan warga. Negara juga harus membuka dan memberdayakan ruang publik secara optimal sebagai instrumen warga dalam menyalurkan aspirasinya, serta menutup keran tumbuh suburnya praktik politik uang baik di kalangan elit politik maupun di kalangan masyarakat, karena dengan membiarkan politik uang berlangsung, maka tidak hanya berimpilkasi melahirkan politisi yang korup dan mengekang hati nurani masyarakat dalam

\footnotetext{
${ }^{22}$ Roy Marthen, Marten Bunga, "Dampak Politik Uang Terhadap Demikrasi”. Jurnal UNNES Volume 4 Nomor 3 Tahun 2018, Fakultas Hukum Universitas Negeri Semarang. Hal 11, diakses tanggal 13 Juli 2019.
}

memberikan partisipasi politiknya, namun juga berakibat tercederainya suatu pemilu yang demokratis.

\section{DAFTAR PUSTAKA}
Cora Elly Noviati, "Demokrasi dan Sistem Pemerintahan", Jurnal Konstitusi Vol. 10 Nomor 2 Juni 2013. Hal 1, diakses Tanggal 10 Juli 2019, pukul 14.40.

Daud M. Liando, "Pemilu Dan Partisipasi Politik Masyarakat (Studi Pada Pemilihan Anggota Legislatif Dan Pemilihan Presiden Dan Calon Wakil Presiden Di Kabupaten Minahasa Tahun 2014)”. Jurnal LPPM Bidang EkoSosBudKum, Volume 3 Nomor 2 Tahun 2016Edisi Oktober, Fakultas Ilmu Sosial dan Ilmu Politik Universitas Sam Ratulangi Manado. Hal 2, diakses tanggal 13 Juli 2019.

Dendy Lukmajati, "Praktek Politik Uang Dalam Pemilu Legislatif 2014 (Studi Kasus di Kabupaten Blora)".Jurnal Politika, Vol. 7, No.1, April 2016. Hal 2, diakses tanggal 12 Juli 2019, Pukul 14.00.

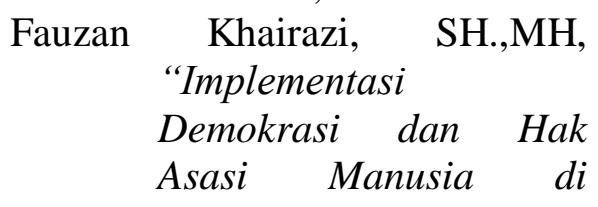


Indonesia”, Jurnal Inovatif Vol. 3 Nomor 1 Januari 2015. Hal 1, diakses 10 Juli 2019, Pukul 14.30.

Gonda Yumitro, "Partai Islam dalam Dinamika

Demokrasi di Indonesia”. Jurnal Ilmu Sosial dan Ilmu Politik, Volume 17 Nomor 1, Juli 2013. Hal 3, diakses tanggal 10 Juli 2019, Pukul 14.45.

Heri Kusmanto, "Partisipasi Masyarakat Dalam Demokrasi Politik". Jurnal Ilmu Pemerintahan dan Sosial Politik Vol 2 Nomor 1 Tahun 2014. Fakultas Ilmu Sosial dan Ilmu Politik, Universitas Sumatera Utara. Hal 9, diakses tanggal 13 Juli 2019.

Heru Nugroho, "Demokrasi dan Demokratisasi : Sebuah Kerangka Konseptual Untuk Memahami Dinamika Sosial-Politik Di Indonesia", Jurnal Pemikiran Sosiologi Vol. 1 Nomor 1 Mei 2012. Hal 1, diakses Tanggal 4 Juli 2019 Pukul 14.00.

Jailani, SH.,MH, "Sistem Demokrasi di Indonesia ditinjau Dari Sudut Hukum Tata Negara", Jurnal Inovatif Vol. 8 Nomor 1 Januari 2015, Hal 1, diakses 4 Juli 2019 Pukul 13.35.

Muhammad Hanafi, "Kedudukan Musyawarah Dan
Demokrasi Di Indonesia". Jurnal Cita Hukum Vol. 1 Nomor 2, Desember 2013. Fakultas Syariah dan Hukum UIN Syarif Hidayatullah Jakarta, Hal 8-9, diakses tanggal 10 Juli 2019, Pukul 14.10.

Nuraini Latuconsina, "Perkembangan

Demokrasi dan Civil Society di Indonesia", Jurnal Populis Vol. 7 Nomor 2 Oktober 2013, Universitas Pattimura Ambon. Hal 1, diakses 4 Juli 2019 Pukul 14.13.

Putera Astomo, "Pembentukan Undang-Undang Dalam Rangka Pembaharuan Hukum Nasional Di Era Demokrasi".Jurnal

Konstitusi, Volume 11, Nomor 3, September $2014 . \quad$ Universitas Sulawesi Barat (UNSULBAR), Hal 2-3, diakses tanggal 10 Juli 2019, Pukul 15.00.

Ria Casmi Arrsa, "Pemilu Serentak dan Masa Depan Konsolidasi Demokrasi”. Jurnal Konstitusi, Volume 11 Nomor 3, September 2014, Universitas Brawijaya, Malang. Hal 8 diakes tanggal 10 Juli 2019, Pukul 15.00.

Roy Marthen, Marten Bunga, "Dampak Politik Uang Terhadap Demikrasi”. Jurnal UNNES Volume 4 Nomor 3 Tahun 2018, Fakultas Hukum 
Universitas Negeri
Semarang. Hal 11 ,
diakses tanggal 13 Juli
2019.

Wahyuningtyas Dwi Saputri,

Bagus Edi Prayogo,

"Tantangan Demokrasi

di Era Globalisasi Demi

Mewujudkan

Pencegahan Politik

Uang Dalam Pemilu",

Jurnal Vol. 4 Nomor 2

Tahun 2018, Fakultas

Hukum Universitas

Negeri Semarang. Hal 3,

diakses tanggal 10 Juli 2019, Pukul 14.50.

Zulkarnain Ridwan, "Cita

Demokrasi Indonesia

dalam Politik Hukum

Pengawasan Dewan

Perwakilan Rakyat

terhadap Pemerintah",

Jurnal Konstitusi Vol. 12

Nomor 2 Juni 2015,

Fakultas Hukum

Universitas Lampung.

Hal 2-3, diakses Tanggal

10 Juli 2019, Pukul

14.15 . 